\title{
Effect of the Weaving Conditions of Air Jet Loom on Mechanical Properties of Weft-Yarn in Woven Fabrics
}

\author{
Atsuji Masuda*, Kazuo Washida* and Nobuo Ogata* \\ *Industrial Technical Center of Fukui Prefecture, Kawaiwashizuka, Fukui, 910-0102, Japan \\ ${ }^{* *}$ Fukui university, Bunkyo, Fukui, 910-0017, Japan
}

\begin{abstract}
The mechanical properties of the fabrics woven by the jet loom are inferior to those of fabrics woven by the rapier or the shuttle looms, although not only the same textile weave was produced but also the same weaving yarns were used. Furthermore, the fabrics woven by the jet loom indicate paper-like features. These drawbacks of the fabrics woven by the jet loom would be caused by the marked deterioration of the yarn properties during the weaving process.

In this work, the influence of weaving conditions of an air jet loom (AJL) on the mechanical properties of weft yarn is investigated. As a result, it is found that the maximum strength and the modulus of elasticity are decreased during the weaving process. However, it is found that there is a weak correlation between the decrease in the modulus of elasticity and that in the strength. Moreover, it is found that the decrease in the modulus of elasticity would be caused by bending strain of the weft yarn, and the decrease in the strength would be caused by the production of the stress concentration in the weft yarn during weaving.
\end{abstract}

Key words ; Air jet loom, Mechanical properties of yarn

(Received Feb. 29, 2000)

(Accepted for Publication Aug. 21, 2000)

\section{ジェットルーム製織条件がよこ糸物性に及ぼす影響}

増田 敦士*, 熟田 一夫*, 小形 信男**

\section{1. 緒 言}

ジェットルームで製織した織物の物性は, 普通織 機やレピア織機で製織した織物の物性と比較して劣 る場合が多い。例えば衣料用織物の場合, ジェット ルーム織物は，他の織機で製織した織物と比較して 織物表面は凹凸感のないペーパーライクなものにな り，風合いの面で劣る場合がある，また，産業資材 用織物の場合，ジェットルームで製織した織物は， 同一規格の織物を作製したとしても，製織前の糸物
性から予想される織物物性が得られない等の現象が 比較的多く生じる.これらの欠点の原因として，ひ とつには製織時に糸の物性自体が変化していること が考えられる。

これまでに，繊維に関しては，紡糸条件と繊維物 性の関係1), 綫維の伸張特性2)やひずみ速度が䋐維 物性に及ぼす影響3 5) など数多くのモデル実験や理 論解析が行われているが，製織工程が糸の物性に及 ぼす影響について検討した例は少ない. 織物に関し ては, 織縮みの研究6,7), 織物中の糸の残留力に関

**会員, 福井大学工学部, 福井市文京 3-9-1, TEL. 0776-27-8939 
する研究8), 織物規格と風合いの関係9)など多数の 研究が行われてきているが，製織方法および製織条 件と織物物性の関係を検討した例10)は少ない。これ らの関係が明らかになれば，製織前の糸物性データ から製織後の織物物性を高い精度で予測することが 可能になり, 織物の企画設計を行うときの重要な情 報となる。

そこで, 本研究では製織条件とよこ系物性の関係 を明らかにすることを目的にエァージェットルーム

（AJL）による製織試験を行い，製織工程の前後に おけるよこ糸物性の変化を測定した．その結果， AJLの製織条件とよこ糸物性の関係を明らかにした ので報告する.

\section{2. 実験方法}

\section{1 織物試料の製織条件}

試料は，エァージェットルーム（侏)豊田自動織機 製作所JAT600）を使用して製織した．使用したた て糸は市販のポリエステルフィラメント糸 $(110$ $\mathrm{dtex} / 48 \mathrm{f})$ に撚糸加工 $(\mathrm{S} 500 \mathrm{t} / \mathrm{m})$ を施したもので あり，よこ糸は市販のポリエステルフィラメント糸 84dtex/36f である。また, 繊維の破断過程観察に は, 市販のポリエステルモノフィラメント糸17dtex を 5 本引き揃えたモデル糸 $(84 \mathrm{dtex} / 5 \mathrm{f}$ ) をよこ系 に使用した。製織は, たて糸張力, よこ糸張力, 織 機回転数, よこ糸密度および織り組織（以後単に組 織と記す）を変化させて行い,この各製織条件の可 変範囲を表 1 に示す．特に指定のない場合は，表中 の標準条件で製織した試料を指す．製織時のたて糸 張力およびよこ系張力は応答周波数 $1 \mathrm{kHz}$ の 3 ピン 式張力計（インテック(侏)製，IH-TY）を使用して測 定した.たて糸張力は織機 1 回転中に観察されたそ の平均值で表し，よこ糸張力は，既報11) と同様によ こ糸フィーダーとブースターノズルの間で測定し， この最大值であるよこ入れ飛走終了時のピーク張力
で表した。作製した織物試料は織機の巻き取りビー ムに巻き取らず，製織直後に温度 $20^{\circ} \mathrm{C} \cdot$ 湿度 $65 \%$ の 条件下に移動させ，一定時間静置した後，この織物 よりよこ糸を抜き出し, 物性試験に供した。

\section{2 糸の物性試験方法}

系の静的力学特性は, 温度 $20^{\circ} \mathrm{C} \cdot$ 湿度 $65 \%$ の条件 下で, 引張試験機（株島津製作所製オートグラフ AGS-1 KNG）を使用して測定した。伸張条件はJIS （L1013）に準拠し, 試長 $200 \mathrm{~mm}$, 引張速度 $200 \mathrm{~mm}$ $/ \mathrm{min}$, 初荷重 $80 \mathrm{mN}$ である。荷重一ひずみ関係を各 種よこ系について測定し，後述する理由によりこの 曲線の300 800 $\mathrm{mN}$ の範囲で弾性率 $M$ を求め, 最 大荷重を示すひずみと荷重より, 強度最大時のひず み $\varepsilon$ と最大強度 $S$ を求めた. 各測定は, 1 条件に 対して少なくとも10回以上行い, 平均值を用いて表 すことにした．また，製織による糸物性の変化は， 製織前の糸物性值 $(M, S$, と $\varepsilon)$ に対する製織後の 糸物性值の比で表し, それぞれ比弾性率 $(r M)$, 比 最大強度 $(r S)$ および比最大ひずみ $(r \varepsilon)$ とした.

糸の動的力学特性は, (株東洋精機製作所製レオグ ラフソリッドを用いて測定した。このときの測定条 件は, 初荷重 $98 \mathrm{mN}$, 試長約 $20 \mathrm{~mm}$, 測定周波数 10 $\mathrm{kHz}$ ，測定温度領域一 50 ～ $220^{\circ} \mathrm{C}$ である.

\section{3 織物試料の製織条件}

断面観察用の試料は, 織物中の糸が移動しないよ うにニトロセルロースで織り構造を固定し,よこ糸 にそって織物を裁断して作製した。断面観察は, マ イクロスコープ顕微鏡（スカラ(侏製ビデオマイクロ スコープVMS-1900）および画像解析処理装置（英 光産業(秼製マイクロメジャーEMM1300）を使用し, 倍率100〜200倍で行った. 織物中のよこ糸屈曲の幾 何学状態は, 次の 2 変数を用いて表現する. すなわ ち, 屈曲しているよこ糸をある曲率半径 $\rho$ を持つ 円で近似し，また， $L$ を用いて織物厚さ方向の長さ

Table 1 Weaving conditions of AJL

\begin{tabular}{|c|c|c|}
\hline Item & Standard condition & Variable range \\
\hline Machine speed (rpm) & 461 & $461 \sim 610$ \\
\hline Warp tension $(\mathrm{mN})$ & 223 & $137 \sim 428$ \\
\hline Weft density (picks/ inch) & 74 & $50 \sim 74$ \\
\hline Weft tension $\quad(\mathrm{mN})$ & 330 & $269 \sim 514$ \\
\hline Textile weave & $\begin{array}{c}1 / 1 \\
\text { (Plain) }\end{array}$ & $\begin{array}{l}\text { 1/1 (Plain) } \\
\text { 1/3, 1/7, 2/2 (Twill) } \\
\text { 2/2, 4/4 (Rib) }\end{array}$ \\
\hline
\end{tabular}


(1)
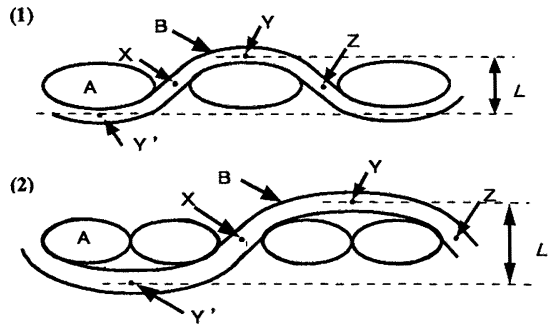

$A:$ Warp yarn, $B:$ Weft yarn, $L:$ Bending length of the weft yarn $X, Y, Z$ : Points for the caluculating radius of curvature of the weft yarn

Fig. 1 Pictures of fabric cross-section; (1) : Plain fabric, (2): Rib $2 / 2$ fabric.

を表現することにする（図 1 )。具体的には， $\rho$ は よこ糸の屈曲方向が変わる屈曲点（図 1 の X, Z) およびよこ糸の屈曲が最大となる点（図1のY）を 通過する円と仮定して求め, $L$ は $\mathrm{Y}$ と $\mathrm{Y}^{\prime}$ 間の距離 として求める。また, 織物中のよこ糸のひずみはク リンプ率 $(C)^{12)}$ を使用して表現する。具体的には, 織物中のよこ糸の長さ $(l)$ を曲率半径 $\rho$ で近似さ れる円弧の長さ(円弧 X, Y, Z) で求め, 図1の $\mathrm{X}, \mathrm{Z}$ 間の距離（lo）との比 $(\mathrm{C}=l / l o-1)$ で表し た.

\section{4 織維表面観察法}

破断過程観察には, 引張試験機を使用して $1.6 \times$ $10^{-2} \mathrm{~s}^{-1}$ のひずみ速度で糸中のフィラメント 1 本に 対し16〜22\%の範囲のひずみを加え，ひずみを維持 したまま両面テープを使用して繊維試料約 $10 \mathrm{~mm}$ を 試料台に固定し，金蒸着を行った試料を使用した。
この金蒸着した繊維の表面を, 電子顕微鏡（侏)日立 製作所・S-2150型）を使用し，倍率1000 1500倍で 観察を行った.

\section{3. 実験結果および考察}

\section{1 製織による平織物中のよこ糸物性変化}

\section{1 .1 製織前のよこ糸物性}

図 2 は,よこ糸に使用したポリエステル糸の荷重 履歴およびひずみ履歴がその弾性率に及ほす影響を 示す. 縦軸の比弾性率は, 糸を $1.6 \times 10^{-2} \mathrm{~s}^{-1}$ のひず み速度で伸張した場合の弾性率と, 同一のひずみ速 度で任意のひずみを糸に付加し，一旦ひずみを取り 除いた後, 再度同じひずみ速度で㵶維が破断するま で伸張したときの弾性率との比を表している，図よ り,ポリエステル糸は $800 \mathrm{mN}$ 以下の荷重範囲 (1.4\%以下のひずみ範囲) 内では，荷重（ひずみ） 除去後も元の糸とほほ同じ弾性率の值を示すが,さ らに荷重（ひずみ）が増加すると急激に弾性率が低 下することがわかる。したがって, 荷重が $800 \mathrm{mN}$ 以下およびひずみが1.4\%以下の場合に糸は弾性限 度内にあると考えられる。この值と表 1 に示す製織 時に作用するよこ糸張力值を比較すると，本実験で 使用する織物の製織工程では，使用した糸の弾性限 度を越える張力はよこ系に付与されていないと考え られる。

\section{1 .2 製織によるよこ糸物性の変化}

製織前のよこ糸と表 1 の基本製織条件で作製した 製織後のよこ糸の強伸度測定結果の一例を図 3 に示
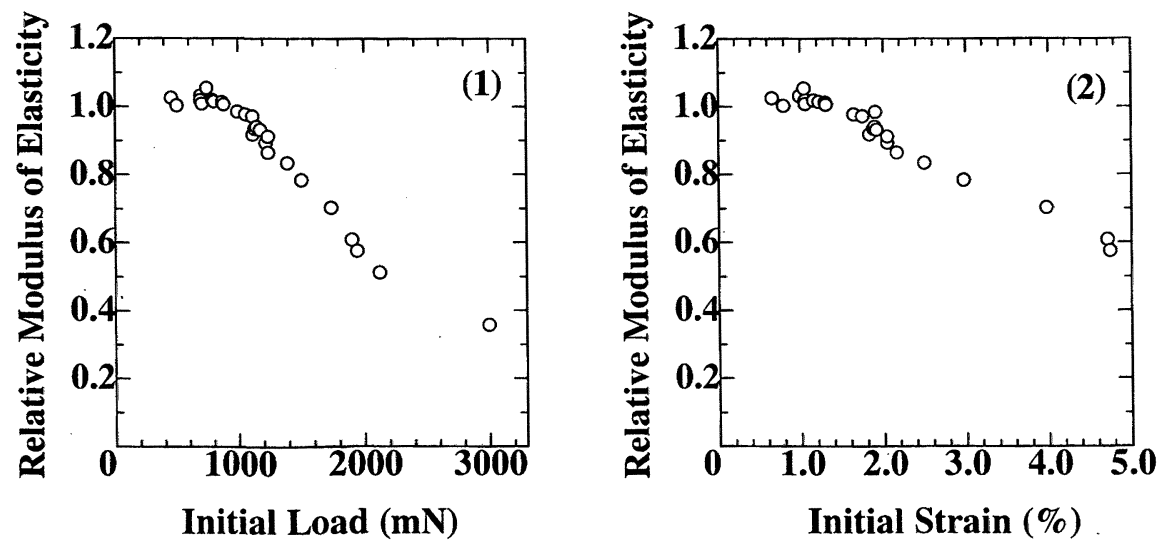

Fig. 2 Effect of the load or strain history on the relative modulus of elasticity; ( 1 ) relation between the relative modulus and the initial load, (2) relation between the relative modulus and the initial strain. 


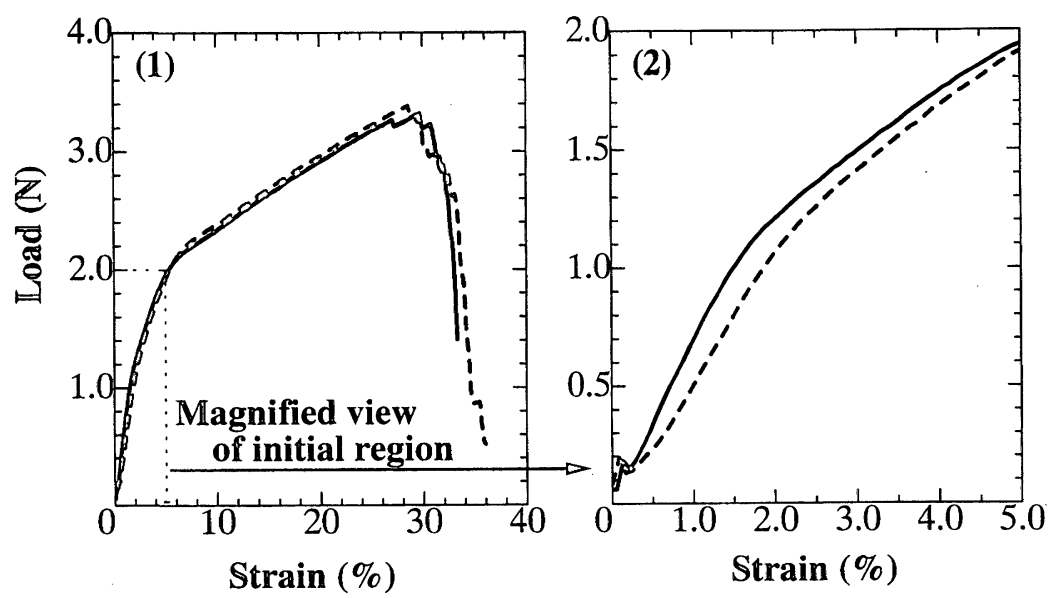

Fig. 3 Effect of weaving on the Load-Strain curves ; solid line : original yarn, broken line : woven yarn.

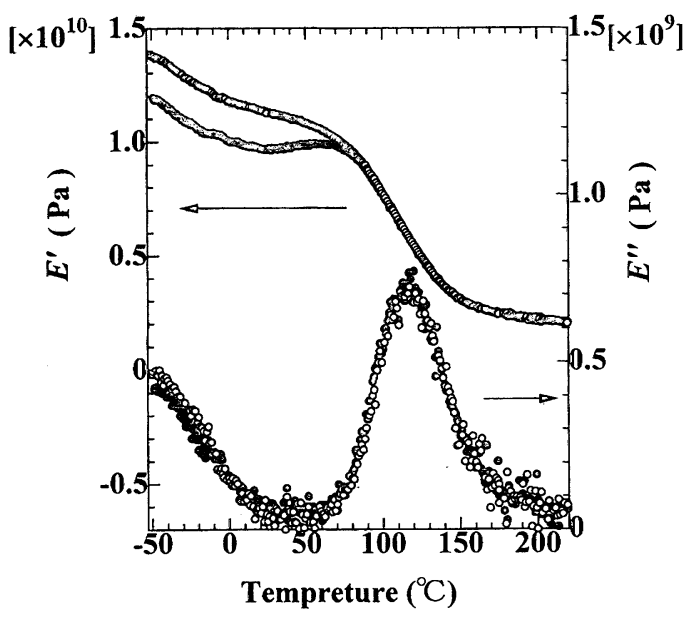

Fig. 4 Dynamic modulus for the woven and the original yarns ; $\bigcirc$ : original yarn, : woven yarn.

す．製織前のよこ糸の強伸度曲線と製織後のそれを 比較すると, 図 3（1）に見られるように全体的に は大きな差が見られず, 最大強度および最大強度を 示すひずみには製織の影響がないことがわかる. 図 3（2）は, 図 3（1）の低ひずみ領域の拡大図で ある.グラフ形状には製織による変化が見られ，製 織後のよこ糸の弾性率が低下していることがわか る.ただし，図3（2）で $0.2 \%$ 以下の低ひずみ領 域で急激な荷重減少が見られるが，これは試験機の 特徵である。すなおち, 試料のチャック切れを防止 するために本試験機のチャックと試料の間には摩擦
面があり，試験開始時に試料がこの摩擦面に密着す る前に滑りが生じ，このグラフ形状が出現したと思 われる.この理由のため, 前述の低ひずみ領域を避 け，かつ図中で直線性が高い荷重300～800 $\mathrm{mN}$ の範 囲から弾性率を求めた.

図 4 は，製織前の糸と表 1 の基本製織条件で作製 した製織後のよこ糸の動的粘弾性挙動を測定した結 果を示す.ポリエステルのガラス転移温度（以下 $\left.T_{\mathrm{g}}\right)$ ，である $80^{\circ} \mathrm{C}$ 以下の温度域で，製織後のよこ糸 の貯蔵弾性率 $\left(E^{\prime}\right)$ が製織前より低下し, それ以上 の温度では, 製織の変化が見られないことがわか

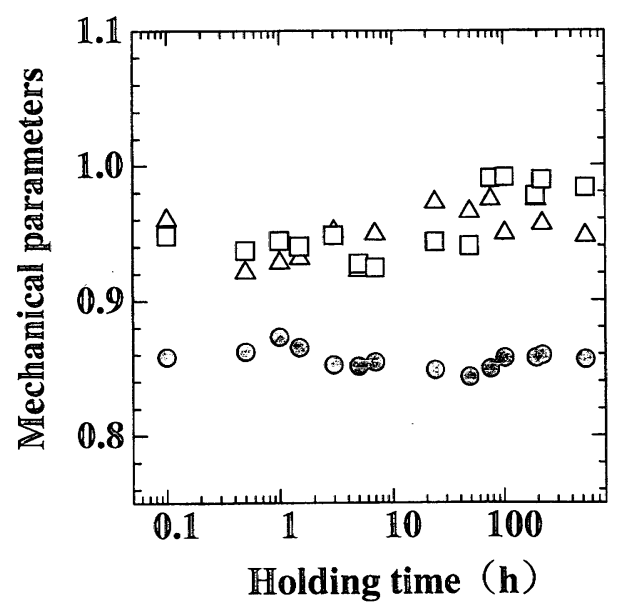

Fig. 5 Effect of the holding time on relative mechanical properties of the weft yarn ; : relative modulus of elasticity, $\square$ : relative strength and $\triangle$ : relative elongation. 
る.この低下は, 製織による静的弾性率の低下の結 果と対応している。 また, 本実験の測定温度範囲内 では損失弾性率 (E”') が製織の前後でほとんど変 化がないことは，興味ある現象である．すなわち， $E^{\prime}$ は $T_{\mathrm{g}}$ 以下の温度域で著しく荷重履歴効果を受け るのに対し，E”は荷重履歴効果をそれほど受けな いことは注目に值し，別途詳細に検討する13).

製織後の時間経過がよこ糸物性に及ぼす影響を困

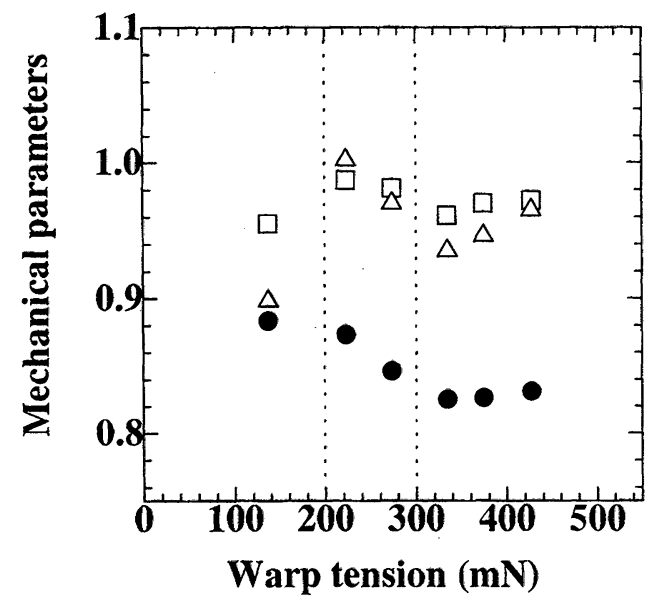

Fig. 6 Effect of warp tension on relative mechanical properties of the weft yarn; 0 : relative modulus of elasticity, $\square$ : relative strength and $\triangle$ : relative elongation.

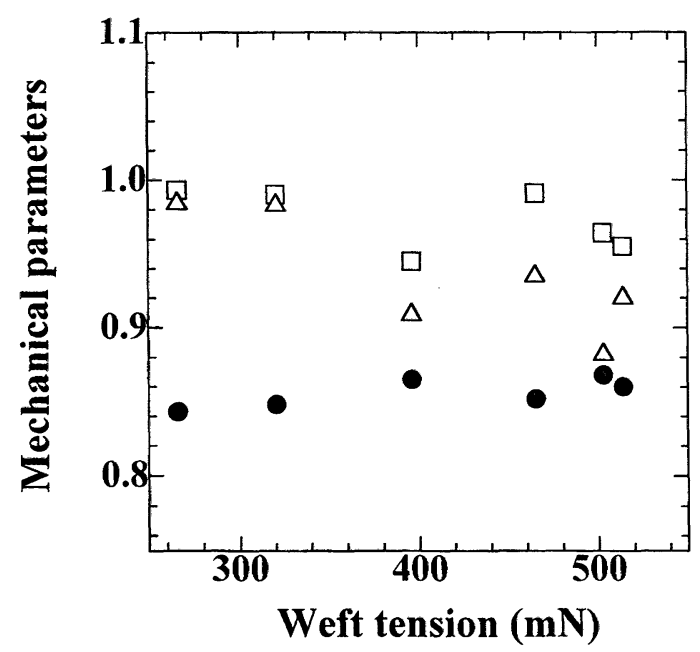

Fig. 7 Effect of weft tension on relative mechanical properties of the weft yarn; 0 : relative modulus of elasticity, $\square$ : relative strength and $\triangle$ : relative elongation.
5 に示す. $r S$ と $r \varepsilon$ は製織直後10時間までは值が低 い傾向にあり，製織後20３0時間以降はほほ一定値 を示す．他方， $r M$ は製織直後からほぼ一定值を示 す.これらの結果より，以後のよこ糸物性測定は， 各物性が安定する製織後50時間経過後に行った。

\subsection{3 各種製織条件がよこ系物性に及ぼす影響}

図 6 は，たて糸張力が製織後のよこ糸物性に及ほ す影響を示す. $r M$ はたて系張力の增加に伴い約

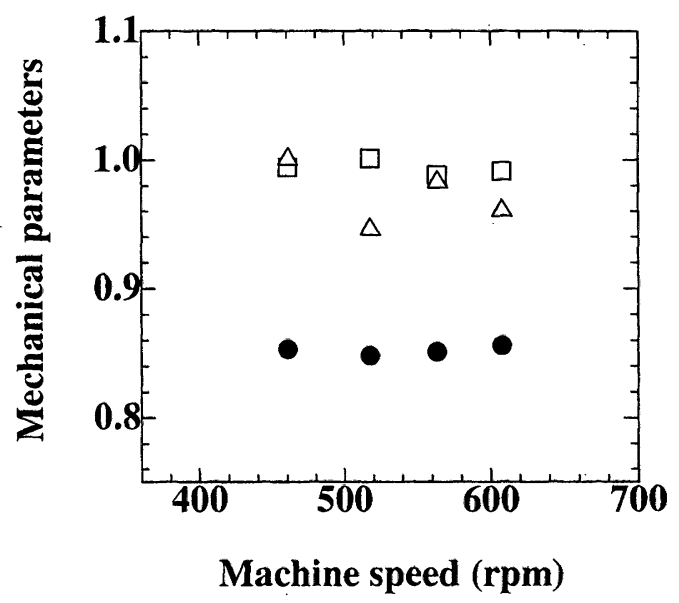

Fig. 8 Effect of the machine speed on relative mechanical properties of the weft yarn; 0 : relative modulus of elasticity, $\square$ : relative strength and $\triangle$ : relative elongation.

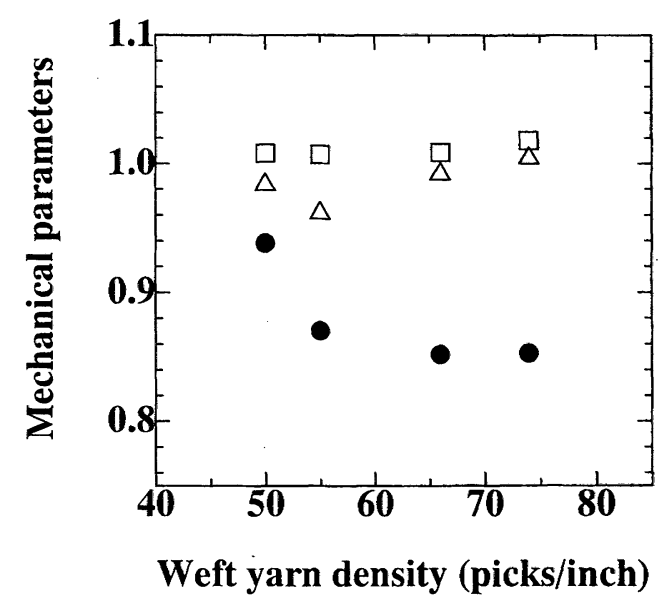

Fig. 9 Effect of the weft yarn density on relative mechanical properties of the weft yarn; : relative modulus of elasticity, $\square$ : relative strength and $\triangle$ : relative elongation. 
15\%減少している。これに対し， $r S$ はたて糸張力 にほとんど依存せず，それは製織前に近い值を示し ている. rとはたて糸張力が低い場合に10\%低下し ているが, それ以外のたて糸張力範囲ではたて糸張 力に依存せず，その值も製織前に近い値を示す.

以上の結果より，たて糸張力が $r M$ に及ぼす効果

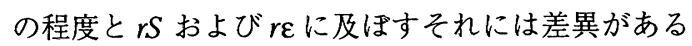
ことがわかる，すなわち，製織条件が $r M$ と $r S$ （ $r \varepsilon$ を含む）の低下に及ぼす機構はそれぞれ異なると推 測される．また，図中の点線で囲われた部分は，一 般にジェットルームで製織する場合に使用されるた て糸張力範囲（たて糸 1 本当たり $2 \sim 3 \mathrm{mN} / \mathrm{dtex}$ ) を示している. 図より, 通常のたて系張力条件でも よこ糸は製織により弾性率が約15\%低下し，たて糸 の開口性を上げるためにたて糸張力を高く設定する と,さらに弾性率が低下することが予想される.

製織時のよこ糸張力と製織後のよこ糸物性の関係 を図 7 に示す. 本実験のよこ糸張力を変えた範囲で は， $r M$ 值はよこ系張力に依存せず，約 $15 \%$ 減少し た一定值を示すことがわかる. 他方, $r S$ 值と $r \varepsilon$ 值 はよこ糸張力の増加に伴い減少することがわかる.

製織時の織機回転数と製織後のよこ糸物性の関係 を図 8 に示す．本実験の織機回転数を変えた範囲内 では, 各物性值とも織機回転数に依存せずに一定值 を示す. $r M$ 值は製織前より約 $15 \%$ 減少した值を示 し, $r S$ および $r \varepsilon$ は製織前に近い值を示すことがわ かる.

よこ糸密度と製織後のよこ糸物性の関係を図 9 に 示す. 60 本/inch 以下のよこ糸密度範囲ではよこ糸
密度の増加に伴い $r M$ が急激に減少し, 60本/inch 以上のよこ糸密度範囲ではよこ糸密度にかかわらず $r M$ が一定值を示すことがわかる．また，本実験の よこ糸密度範囲では, $r S$ および $r \varepsilon$ はこ糸密度に 依存せず，それらは製織前に近い物性值を示すこと がわかる。

以上の結果をまとめると $r M, r S$ および $r \varepsilon$ は製 織により低下するが, その低下の傾向が $r M$ と $r S$

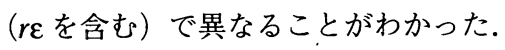

\section{2 各種組織がよこ糸物性に及ぼす影響}

組織を変えた場合のよこ系物性測定結果を図10に 示す. 図中の組織の種類を表す数值は, 組織最小繰 り返し単位のたて糸がよこ糸に対して上にあるか下 にあるかを表現している．例えば，1/1は平織り を示し, 組織の最小繰り返し単位がたて糸 2 本で構 成され, 最初のたて糸はよこ糸の上にあり, 次のた て糸がよこ糸の下にあることを示している. 図よ り, 組織により $r M, r S$ および $r$ が変化している ことがわかる. 特に, 組織変化に対する $r M$ と $r S$ および $r \varepsilon$ の関係は逆の傾向を示し, 平組織では $r M$ の低下が大きく, $r S$ および $r \varepsilon$ の低下は小さい.こ れに対し, 綾 $1 / 7$ やよこ畧 $4 / 4$ 組織では $r M$ の低 下は小さく, $r S$ および $r \varepsilon$ の低下が大きいことがわ かる。これらの結果より, 製織条件が $r M$ に及ほす 影響と $r S(r \varepsilon)$ に及ぼす影響の間には相関が低い ことが明らかである。そこで，次に $r M$ と $r S(r \varepsilon)$ を支配する因子を求める.

よこ糸曲率半径 $\rho$ と製織後のよこ糸物性変化の
(1)

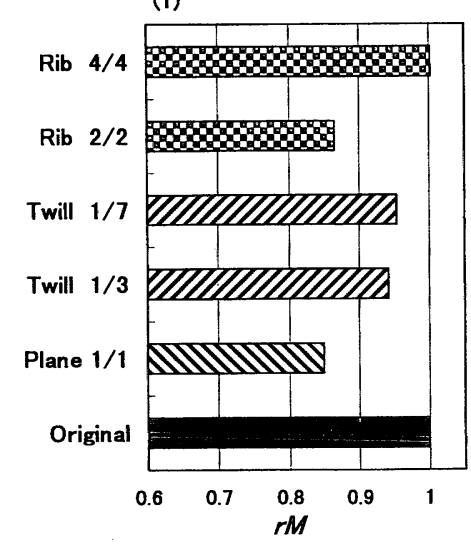

(2)

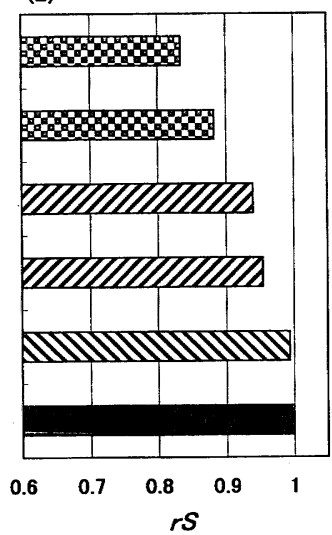

(3)

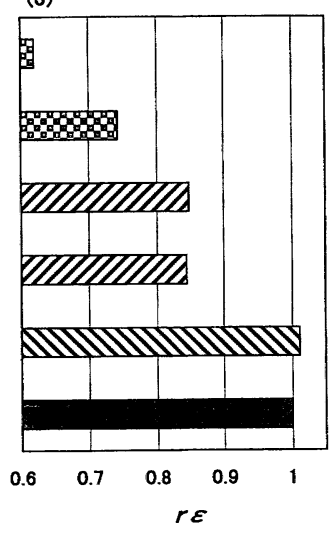

Fig. 10 Effect of the fabric weaving patterns on relative mechanical properties of the weft yarn ; (1) : relative modulus of elasticity, (2) : relative strength and (3): relative elongation. 


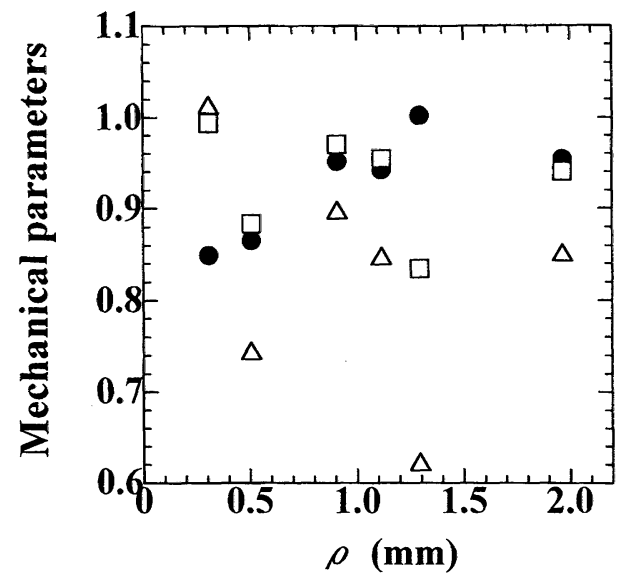

Fig. 11 Effect of the radius of curvature of the weft yarn on relative mechanical properties of the weft yarn ; $:$ relative modulus of elasticity, $\square$ : relative strength and $\triangle$ : relative elongation.

関係を求め, その結果を図11に示す．図より， $r M$ は $\rho$ の減少に伴い直線的に低下しているのに対 $し, r S$ および $r \varepsilon$ との間の相関は低いことがわか る.この結果は, $r M$ は $\rho$ により大き支配されて いることを意味する，次に，よこ糸屈曲の範囲を示 すパラメータ $L$ と製織後のよこ糸物性変化の関係 を図12に示す．図より，rS および $r \varepsilon$ は $L$ 増加に ともない低下しているのに対し,$r M$ と $L$ の間の相

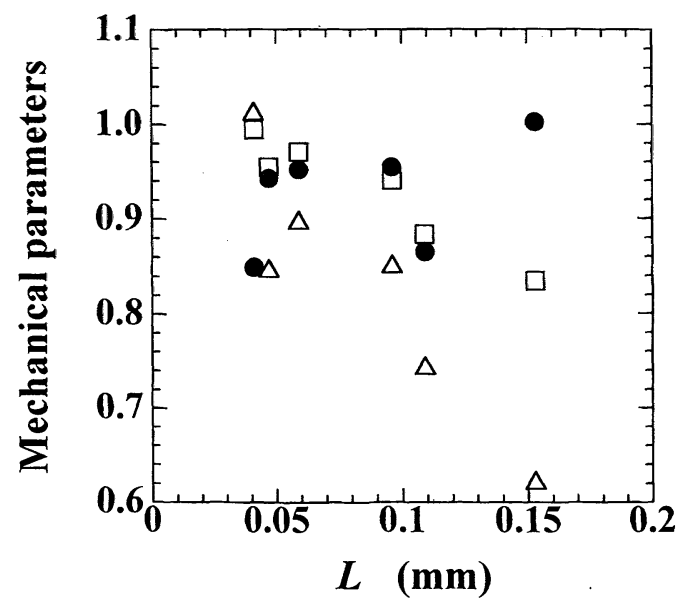

Fig. 12 Effect of the bending length of the weft yarn on relative mechanical properties of the weft yarn; : relative modulus of elasticity, $\square:$ relative strength and $\Delta$ : relative elongation.
関は低いことがわかる。この結果は, $r S$ および $r \varepsilon$ は $L$ にり強く支配されていることを意味する。 このように, $r M$ は $\rho$ の増加に伴って増加するが $L$ に強く依存しないこと, 他方, $r S$ および $r \varepsilon は L の$ 増加に伴って低下するが $\rho$ にあまり依存しないこ とは興味ある実験結果である.

ここで，よこ糸に加わる荷重履歴として，よこ糸 張力の他によこ糸插入後の織り構造形成時に生じる よこ糸の屈曲が考えられる．この屈曲によるよこ糸 のひずみは, 織り構造形成直後のよこ糸のひずみ量 と等しいと考える．そこで，製織直後の機上から織 り構造を固定した織物試料を取り出して断面計測を 行い，その織物中のひずみ量（クリンプ率）を求 め,このひずみ量とよこ糸に使用した糸の弾性限界 の図2（2）を比較し，織り構造形成時に生じるよ こ糸のひずみにより発生する $r M$ の減少率を推定し た。この $r M$ の減少率と実測の引張試験による $r M$ の減少率を表 2 に示す. 平織り,よこ畧 $4 / 4$ とも によこ糸のひずみ量から推測される $r M$ の減少率と 実測の引張試験による $r M$ の減少率がほほ一致す る。また，一般にたて糸張力とよこ糸密度はよこ糸 のひずみに大きく影響することが知られてお n6,7)，3.1節でこれらの製織条件が $r M$ の減少に影 響することを示している．したがって，弾性率の低 下は織構造形成時によこ糸が屈曲するときに生じる ひずみに起因すると推測される.

また, $r S$ および $r \varepsilon$ 低下の原因は, 織り組織形成 時によこ糸に発生する応力集中と製織後の織物と織 機部材との摩擦が考えられる。そこで, 摩擦が $r S$ 低下に及ぼす影響を検討するために，織機部材と織 物との接触を考慮して機上の織物を 4 区域に分け, 各区域の織物中からよこ糸を採取し，そのよこ糸物 性を調べた（表 3). PositionA は織り前とフェルプ レート（FP）間であり, 織物は織機部材と接触し ない. PositionB はFPとサーフェイスローラー (SR）間にあり，織物は FPに接触する. PositionC は SR とプレスローラー（PR）の間にあり，この区 間で織物は SR と PR に接触する. PositionD は PR 以後の巻き取られるまでの区間である. PositionA 〜D の順に織物と織機部材の摩擦は増加しているの

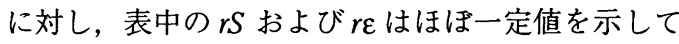
いることから, 織物と織機部材の摩擦が $r S$ および $r \varepsilon$ の低下に及ぼす影響は小さいと考えられる。し たがって，rS および $r \varepsilon の$ 低下は，よこ糸屈曲時に 生じる応力集中が主な原因と推測され, 材料力学の 
Table 2 Effects of strain of weft yarn in the fabrics on decreasing rate of $r M$

\begin{tabular}{|c|c|c|c|}
\hline Textile weave & A (\%) & B (\%) & C (\%) \\
\hline Plain & 2.3 & 17 & 15 \\
\hline Rib 4/4 & 1.8 & 3 & 0 \\
\hline
\end{tabular}

A : Strain of the weft yarn estimated from the crimp ratio

$\mathrm{B}$ : Decreasing rate of $r M$ estimated

from the strain shown in the column A and Fig2-(2)

$\mathrm{C}$ : Decreasing rate of $r M$ estimated from the Load-Strain of the weft yarns

in the fabrics

Table 3 Effects of the fiber collecting position in the loom on relative mechanical properties.

\begin{tabular}{|c|c|c|c|c|}
\hline Item & Position A & Position B & Position C & Position D \\
\hline$r S$ & 0.83 & 0.83 & 0.86 & 0.85 \\
\hline$r \varepsilon$ & 0.63 & 0.61 & 0.69 & 0.66 \\
\hline
\end{tabular}

Position A: front of fabric - fell plate (temple)

Position B: fell plate (temple) - surface roller

Position C: surface roller - press roller

Position D: press roller - cloth roller

観点からは $\rho$ に依存すると考えられるが，このこ とが実験結果に反映されていない。この原因とし て，製織の際に繊維のマイグレーションが生じ，糸 内部の纎維のひずみが均一化することが考えられ

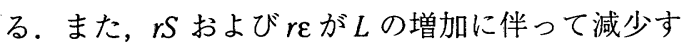
る機構として，応力集中する場所の増加が考えられ る.

以上の結果より, 糸の弾性限度内の張力しか付加 されない製織条件であっても，よこ系物性は製織条 件により変化することがわかった．特に，製織条件 が製織後のよこ糸の比弾性率に及ぼす影響とそれが 比最大強度および比ひずみに及ぼす影響は傾向が異 なり，それぞれ異なった機構が㗢いている．よこ糸 の比弾性率の低下は織り構造形成時によこ糸が屈曲 する影響が大きく, たて糸張力, よこ糸密度の増加 にともないよこ系の比弾性率は低下し, 特に, 織り 組織のよこ糸曲率半径 $\rho$ の減少にともないよこ糸 の比弾性率は約15\%低下することがわかった，ま た, よこ糸張力の増加および織物中のよこ糸屈曲量 Lの増加に伴いよこ系の比最大強度, 比ひずみは減 少することがわかった。

\section{3 製織がよこ糸破断過程に及ぼす影響}

よこ糸の比最大強度が低下する原因を探るため, 製織前のよこ糸の破断過程と図10で製織後の $r S$ が 大きく低下したよこ畧 $4 / 4$ 組織のよこ糸のそれを
比較した．破断過程の観察を容易にするために,よ こ糸にはポリエステル84dtex/ $5 \mathrm{f}$ のモデル糸を使用 した，図13は，付加するひずみを変えたいくつかの 繊維表面を観察し, クラックの発達段階順に並べた 結果である. 繊維表面のクラック形状を観察する と, この繊維の破断過程は 2 種類あることがわか る.ひとつは瀻維軸方向に直線状のクラックが入 り, そのクラックが菱形にひろがり破断に至る場合 であり，このクラックをタイプ $\mathrm{A}$ と表現する.夕 イプAには, 単独にクラックが発生する場合 (Type A-I ) と, クラックが繊維軸方向に連続的 に発生する場合（Type A-II）があり, クラックは 図中(1)〜(4)の番号にしたがって進展し破断に至る. もうひとつは, 繊維軸に対し垂直方向にクラックが 入る場合であり，このクラックをタイプ B と表現 する (Type B). タイプBのクラックも図中(1) (4) の番号にしたがって進展して破断に至る.特に, (2) および(3のクラック形状は明らかにタイプ A とは 異なることがわかる.

製織前のよこ糸とよこ畒 $4 / 4$ 組織のよこ糸の緎 維試料30本以上に対し, 決められたひずみを付加 し，このひずみを付加した段階で試料が未破断の場 合はその繊維表面を電子顕微鏡で観察した。そし て，前述の繊維の破断タイプを参考にして各試料の 破断過程を, 繊維表面にクラックが観察されない場 合を No-crack, タイプ Aのクラックのみ観察され 

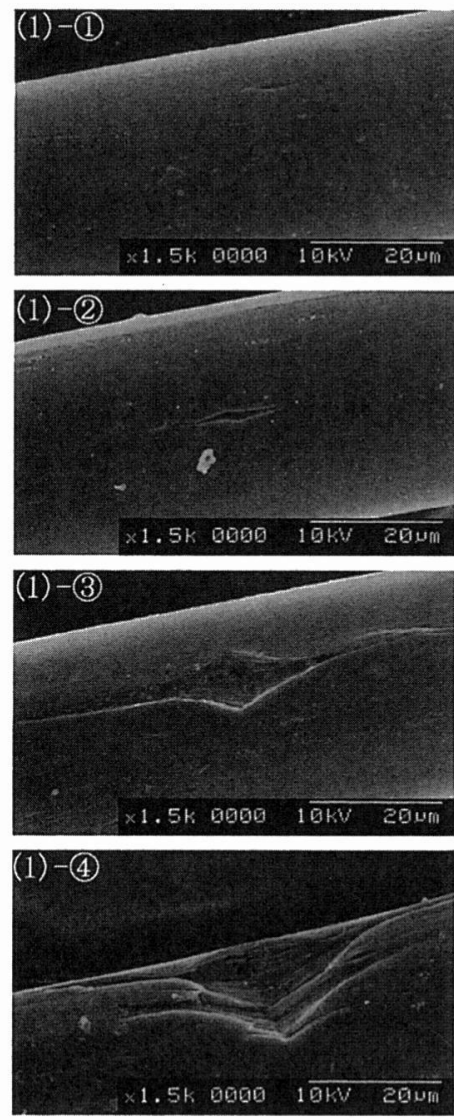

(1) Type A- I
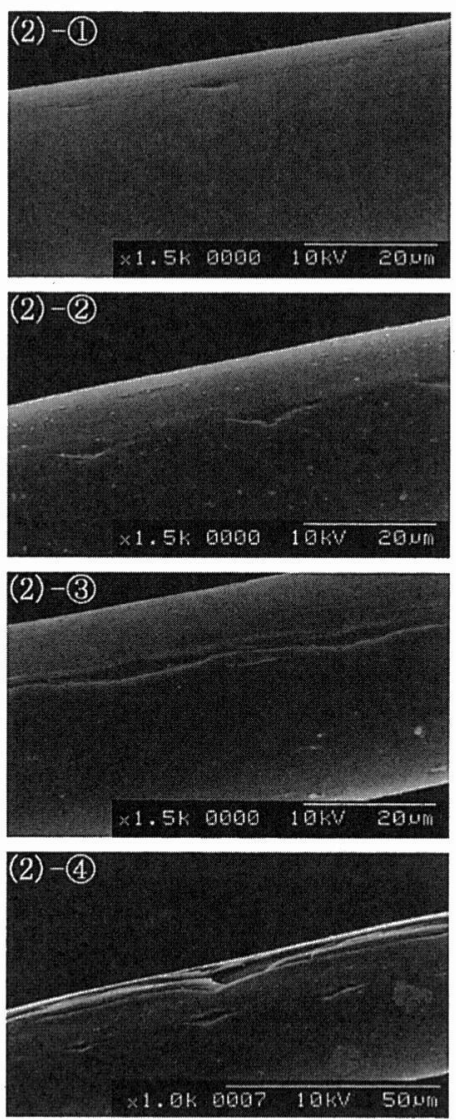

(2) Type A-II
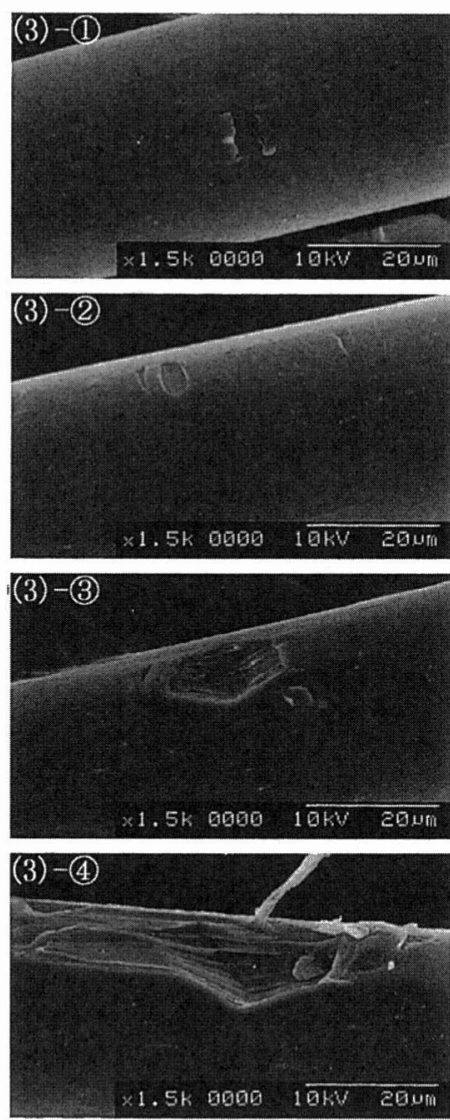

(3) Type B

Fig. 13 Scanning electron micrographs of polyester fibers; the strain of fiber increases with increasing the number in the circle.

た場合を Type-A, タイプ B のクラックが1か所で も観察された場合を Type-B と分類した. 図14は付 加したひずみ量と各破断タイプの割合を表してい る。ただし，図（1）は未破断試料数に対する Nocrackの割合を, 図（2）は未破断試料数に対する Type-Aの割合を, 図（3）は未破断試料数に対す る Type-Bの割合を表している。図（1）より，同 一ひずみでも，製織前のよこ糸の方が副 $4 / 4$ のよ こ糸よりクラックが観察されない割合が高く, 製織 前のよこ系と比較してよこ畧 $4 / 4$ のよこ系はク ラックが発生しやすくなっていることがわかる.図 （2）より，製織前のよこ系の場合は, タイプ A の割合がひずみの増加に伴い増加しているのに対 し，よこ畧 $4 / 4$ のよこ糸の場合は, タイプAの割 合がひずみ量に依存せず比較的一定であることがわ かる。図（3）より,タイプ Bの割合は, 製織前 のよこ糸およびよこ畧 $4 / 4$ の場合にかかわらずひ
ずみの増加に伴い増加しており，よこ畧 4/4の場 合の方が製織前のそれより増加する割合が若干高い ことがわかる. 以上の結果より，製織によりクラッ クの発生が増加するだけでなく, タイプBのク ラックの割合が増加し，これらがよこ畧 $4 / 4$ 織物 のよこ糸の $r S$ および $r \varepsilon か ゙$ 低下する原因のひとつと 推測される.

\section{4. 結 論}

エアージェットルームの製織条件がよこ系の物性 に及ぼす効果を検討した結果，次のことが明らかに なった。

(1)織物製織工程でよこ糸張力が糸の弾性限度内で あっても, 製織後の最大強度・最大強度ひずみ・弾 性率・貯蔵弾性率 $\left(T_{\mathrm{g}}\right.$ 以下の温度領域 $)$ などのよ こ糸物性值が低下する。この弾性率が低下する現象 と最大強度および最大強度ひずみが低下する現象 


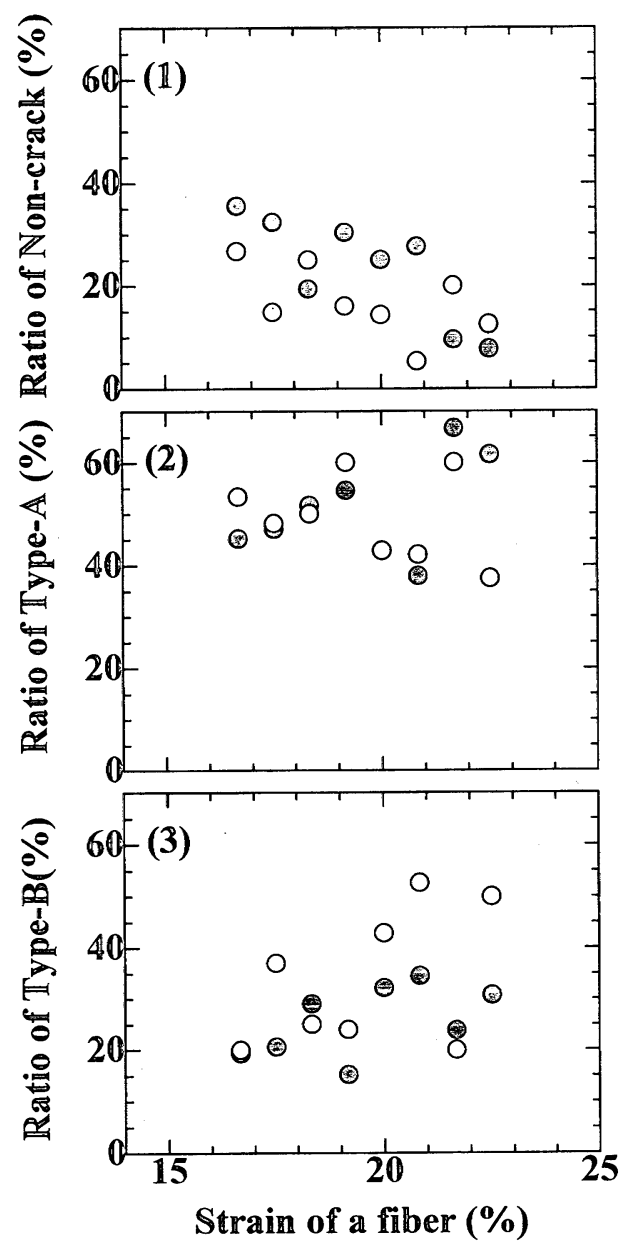

Fig. 14 Effect of the weaving pattern on breaking patterns of the fiber in the yam; : original yarn and $\bigcirc$ : fiber in $\mathrm{Rib} 4 / 4$ fabric.

は，それぞれ独立の現象として取り扱うことができ る.

(2)よこ糸弾性率が製織の時に低下する主因として， 織り構造形成時によこ糸が屈曲することにより生じ る瀻維軸方向の荷重（ひずみ）が考えられる.

(3)よこ糸張力の増加および織り組織のよこ糸屈曲量 の増大に伴いよこ糸の最大強度・最大強度ひずみは
低下する。この最大強度および最大強度ひずみが低 下する現象は，製織時の織り構造形成時によこ糸に 加わるひずみが屈曲箇所に集中することが原因と推 測される，具体的には，この応力集中が原因で繊維 に生じるクラック数が増加するだけでなく, 繊維軸 と垂直方向に発達するクラックが増加し, その結 果, 製織後のよこ系最大強度と最大強度ひずみが低 下することが考えられる。

今後は, ウォータージェットルーム, レピアルー ムやシャトルルームなどを使用して同様の実験を行 い，製織条件が糸物性に及ぼす影響について他の織 機との比較・検討を行いたい.

(謝辞) 本研究の実験に協力してくれた福井大学 学生山崎周亮君に感謝します。

(追記) 本研究の一部は, 纎維機械学会北陸支部 研究発表会（1999.12. 高岡）および繊維機械学会 年次大会（2000. 6. 大阪）にて口頭発表した。

\section{Reference}

1) Sen-i Gakkai, "Saishin no Boushigijutu", P27, Koubunshi Kankoukai Co. (1992)

2) S. Kawabata M. Niwa and S. Nakabayashi ; Text. Mach. Soc. Japan (Japanese Ed), Vol. 28, T153-156 (1975)

3) T. Kinari, A. Hojo, S. Shintaku and N. Iwaki ; Sen-i Gakkaishi, (Japanese Ed), Vol. 46, 311-317 (1990)

4) T. Kinari, A. Hojo, S. Shintaku and N. Iwaki ; Text. Mach. Soc. Japan (Japanese Ed), Vol. 44, T118-125 (1991)

5) A. Bossmann, M. Beier and E. Scholleyer ; Textile Praxis International, Feb., P111-113 (1989)

6) M. Chino, M. Tanaka and M. Suzuki ; Sen-i Gakkaishi (Japanese Ed), Vol. 37, T502-508 (1981)

7) M. Chino and M. Suzuki ; Sen-i Gakkaishi (Japanese Ed), Vol. 33, T272-279 (1977)

8) M. Niwa and S. Kawabata ; Text. Mach. Soc. Japan (Japanese Ed), Vol. 26, T208-215 (1973)

9) S. Kawabata, "Huuaihyouka no hyoujunka to kaiseki", $P$ 6, Text. Mach. Soc. Japan (1980)

10) S. J. Kim, G. D. Yeo, M. H. Park and T. H. Kim ; The 5 th Asian Textile Conference, P1032-1035 (1999)

11) K. Yoshida, S. Kawabata and J. Hasegawa;Text. Mach. Soc. Japan (Japanese Ed), Vol. 40, T99-108 (1987)

12) Text. Mach. Soc. Japan, "SenikougakuIV", P164, Text. Mach. Soc. Japan (1991)

13) A. Masuda and N. Ogata ; Unpublished data. 